\title{
Vanillin Prevents Doxorubicin-Induced Apoptosis and Oxidative Stress in Rat H9c2 Cardiomyocytes
}

\author{
Ivana Sirangelo ${ }^{1, *}$, Luigi Sapio ${ }^{1}$, Angela Ragone ${ }^{1}$, Silvio Naviglio ${ }^{1}$, Clara Iannuzzi ${ }^{1}{ }^{(\mathbb{C}}$, \\ Daniela Barone $^{2} \mathbb{D}$, Antonio Giordano ${ }^{3,4} \mathbb{D}$ and Margherita Borriello ${ }^{1}$ \\ 1 Department of Precision Medicine, Università degli Studi della Campania "Luigi Vanvitelli”, \\ Via L. De Crecchio 7, 80138 Naples, Italy; luigi.sapio@unicampania.it (L.S.); \\ angela.ragone@unicampania.it (A.R.); silvio.naviglio@unicampania.it (S.N.); \\ clara.iannuzzi@unicampania.it (C.I.); margherita.borriello@unicampania.it (M.B.) \\ 2 Cell Biology and Biotherapy Unit, Istituto Nazionale Tumori-IRCCS—Fondazione G. Pascale, \\ 80131 Napoli, Italy; d.barone@istitutotumori.na.it \\ 3 Sbarro Institute for Cancer Research and Molecular Medicine, Center for Biotechnology, \\ College of Science and Technology, Temple University, Philadelphia, PA 19122, USA; giordano@temple.edu \\ 4 Department of Medical Biotechnology, University of Siena, 53100 Siena, Italy \\ * Correspondence: ivana.sirangelo@unicampania.it
}

Received: 6 July 2020; Accepted: 28 July 2020; Published: 1 August 2020

check for updates

\begin{abstract}
Doxorubicin (doxo) is an effective anticancer compound in several tumor types. However, as a consequence of oxidative stress induction and ROS overproduction, its high cardiotoxicity demands urgent attention. Vanillin possesses antioxidant, antiproliferative, antidepressant and anti-glycating properties. Therefore, we investigated the potential vanillin protective effects against doxo-induced cardiotoxicity in $\mathrm{H} 9 \mathrm{c} 2$ cells. Using multiparametric approach, we demonstrated that vanillin restored both cell viability and damage in response to doxo exposure. Contextually, vanillin decreased sub-G1 appearance and caspase-3 and PARP1 activation, reducing the doxo-related apoptosis induction. From a mechanistic point of view, vanillin hindered doxo-induced ROS accumulation and impaired the ERK phosphorylation. Notably, besides the cardioprotective effects, vanillin did not counteract the doxo effectiveness in osteosarcoma cells. Taken together, our results suggest that vanillin ameliorates doxo-induced toxicity in $\mathrm{H} 9 \mathrm{c} 2$ cells, opening new avenues for developing alternative therapeutic approaches to prevent the anthracycline-related cardiotoxicity and to improve the long-term outcome of antineoplastic treatment.
\end{abstract}

Keywords: doxorubicin; ROS; vanillin; H9c2 cells; chemopreventive agents; antioxidant; cardiotoxicity

\section{Introduction}

Classified as an anthracycline antibiotic, doxorubicin (doxo) is an effective anti-neoplastic drug in a broad range of cancers, including breast cancer, leukemia, lymphoma and other solid tumors [1,2]. Nevertheless, due to its pervasive cardiotoxic effects, long-term doxo administration is usually not recommended in cancer patients. Indeed, despite the beneficial effects in tumor progression, doxo-mediated cardiovascular diseases are quite frequent in long-term cancer survivors, where they may significantly contribute to heart failure and death [3,4]. To date, several mechanisms have been implicated in the doxo-induced cardiotoxicity, such as increased oxidative stress and lipid peroxidation, DNA damage, apoptosis and, more recently, autophagy [5]. However, increased reactive oxygen species (ROS) production remains the major mechanism associated with doxo-induced oxidative stress, mitochondria injury and cellular apoptosis in cardiac cells [6-9]. The restricted antioxidant enzymes pool, especially catalases, in cardiac cells are often inadequate to counteract the ROS production amount during doxo administration [10,11]. 
In order to reduce the doxo-related cardiac injuries, several approaches have been proposed, including the usage of new doxo formulations, less toxic, but always effective against cancer cells and cardioprotective supplemental therapies. Currently, the employment of additional cardioprotective agents is strongly recommended as coadjutant procedure in alkylating-based treatment [12-14]. In this respect, significant efforts have been accomplished in order to identify novel and more effective adjuvant agents against doxo-induced cardiotoxicity. Several molecules, such as beta blockers, angiotensin receptor blockers, dexrazoxane, have also been explored in preclinical studies [15-17]. However, a concomitant reduction in anti-cancer efficacy and side effects intensification have radically hampered the following clinical trials investigation $[18,19]$. Recently, due to their well-known antioxidant properties, many attentions have been paid to the plant-derived polyphenols as a possible strategy in the prevention of doxo-induced cardiotoxicity $[5,20,21]$. Speaking of which, it has been reported that curcumin, a natural phenol abundant in turmeric, is able to ameliorate the doxo-induced cardiotoxic effect both in vitro and in vivo studies [22-24]. The mechanisms by which curcumin acts as cardioprotective compound seems to be related to the attenuation of oxidative stress, inflammation and associated cell death pathways [23,25-28]. However, it should be clarified that only upon curcumin pre-treatment a protective effect has been observed, whereas concomitant curcumin-doxo treatment potentiated the cardiotoxicity $[28,29]$. Despite the multiple evidence in support of curcumin efficacy and safety, its application as a potential chemotherapeutic and/or cardioprotective agent is strongly hindered by its poor bioavailability and low aqueous solubility [30,31]. At physiological $\mathrm{pH}$, curcumin is rapidly hydrolyzed and, even after high-doses administration, only minimal fluctuations have been revealed in in vivo models $[32,33]$. With the purpose of identifying the agents responsible for the beneficial curcumin properties, the analysis of the curcumin-related degradation products has recently received more attention, especially in the oncological field $[34,35]$. Among the others, vanillin, the major component of vanilla bean extract, is one of the main and stable degradation products of curcumin [34-36]. Vanillin is a widely known antioxidative, anti-apoptotic, anti-inflammatory, neuroprotective and anticancer compound [37-39]. However, no data are currently available concerning the vanillin-mediated cardioprotective features. For this reason, and taking into account all the mentioned perspectives, the present study has been designed to assess the consequences of vanillin treatment on doxo-induced cardiotoxicity. Using a broadly cardiomyocytes in vitro model, and employing a multiparametric approach, we determined the consequences of vanillin administration in H9c2 cells both as single agent and in combination with doxo. Additionally, with the intention of supporting the usage of vanillin as an effective antagonist just only toward cardiotoxicity and not against doxo efficacy in cancer cell, an identical experimental strategy has also been applied to a representative osteosarcoma model, an aggressive tumor in which doxo still represents one of the only effective weapons [40].

\section{Materials and Methods}

\subsection{Materials}

Doxorubicin (D1515), vanillin (V1104), 3-(4,5-dimethylthiazol-2-yl)-2,5-diphenyl-tetrazolium bromide (MTT) (Sigma-Aldrich Co., St. Louis, MO, USA). Antibodies: anti-Cleaved Caspase-3 (Asp175) (5A1E) (\#9664); anti-p44/42 MAPK (ERK1/2) (\#9102), anti-phospho-p44/42 MAPK (ERK1/2) (Thr202/Tyr204) (\#9101) (Cell Signaling Technology). anti-PARP (\#P7605), anti-PARP (Cleaved-Asp214) (\#SAB4500487), anti- $\beta$-actin AC-74 (\#A2228) (Sigma-Aldrich). anti- $\alpha$-tubulin (B-7) (sc-5286) (Santa Cruz Biotechnology). Secondary antibodies: goat anti-rabbit (GtxRb-003-DHRPX) and goat anti-mouse (GtxMu-003-EHRPX.0.05) (Immunoreagents, Inc.). 


\subsection{Cell Cultures and Treatments}

Embryonic rat cardiac tissue-derived H9c2 cardiomyoblasts (ATCC ${ }^{\circledR}$ CRL-1446) and human U2OS osteosarcoma cells (ATCC ${ }^{\circledR}$ CRL-1446) were cultured in Dulbecco's minimum essential medium (DMEM) (AL007, Microgem, Naples, Italy) supplemented with 10\% FBS, 2.0-mM glutamine (X0550, Microgem), 100 units/mL penicillin and $100-\mathrm{mg} / \mathrm{mL}$ streptomycin (A001, HiMedia) in a 5.0\% $\mathrm{CO}_{2}$ humidified environment at $37^{\circ} \mathrm{C}$. Cells were grown for $18 \mathrm{~h}$ before starting treatments. The experimental groups were: UT: untreated cells; doxo: cells treated with doxo $20-\mu \mathrm{M}$ for $24 \mathrm{~h}$; Pretr: cells pretreated with $100-\mu \mathrm{M}$ vanillin for $18 \mathrm{~h}$ and then treated with doxo $20-\mu \mathrm{M}$ for $24 \mathrm{~h}$; Cotr: cells treated in parallel with vanillin $100-\mu \mathrm{M}$ and doxo $20-\mu \mathrm{M}$ for $24 \mathrm{~h}$; Van: cells treated with vanillin $100 \mu \mathrm{M}$.

\subsection{MTT Assay}

Cell viability was assessed through the ability of cells to reduce the metabolic dye 3-[4-dimethylthiazol-2-yl]-2,5-diphenyltetrazolium bromide (MTT) to a blue formazan product. After treatments, cells were rinsed with phosphate buffer solution (PBS). A stock solution of MTT $\left(5-\mathrm{mg} / \mathrm{mL}\right.$ in PBS) was diluted ten times in cell medium and incubated for $3 \mathrm{~h}$ at $37^{\circ} \mathrm{C}$. After removing the medium, cells were treated with isopropyl alcohol, $0.1-\mathrm{M} \mathrm{HCl}$ for $20 \mathrm{~min}$. Levels of reduced MTT were assayed by measuring the difference in absorbance between 570 and $690 \mathrm{~nm}$. Data are expressed, as percentage reduction of MTT with respect to the control \pm S.D. Data were obtained from five independent experiments carried out in triplicate.

\subsection{Evaluation of LDH, AST and ALT Activities}

The activity of lactate dehydrogenase, (LDH), aspartate aminotransferase (AST) and alanine aminotransferase (ALT) intracellular enzymes was evaluated in the media of each experimental groups, using the Abbott Lab Chemistry Analyzer ci 8200. Relative enzyme activity was determined in accordance with the manufacturer's instructions.

\subsection{Trypan Blue Assay}

To determine the number of dead cells in the experimental groups, Trypan Blue assay was employed. Trypan Blu is a cell membrane-impermeable dye and, therefore, its presence inside the cells is due to damaged membranes. Upon the entry into the cells, Trypan Blue renders the cells dark blue. Briefly, cells were seeded in 10\% FBS-containing medium in a 6-well plate at a density of $1 \times 10^{5} \mathrm{cell} /$ well for $18 \mathrm{~h}$ at $37^{\circ} \mathrm{C}$ and then treated as above described. After $24 \mathrm{~h}$ of treatment, cells were collected and cell counting was performed by mixing $10 \mu \mathrm{L}$ of cell suspension with an equal volume of Trypan Blue $(0.4 \%, v / v)$. The number of blue stained cells (dead) was recorded. For U2OS experiments, besides the number of blue stained cells (dead cells), also not-stained cells (viable cells) were counted. Trypan Blue experiments were performed three times (in replicates of six wells for each data point in each experiment). Data are presented as means \pm standard deviation for a representative experiment.

\subsection{DAPI Nuclear Staining}

Changes in nuclear morphology were evaluated using DAPI fluorescent dye. After treatments, H9c2 cells were fixed with $3 \%$ paraformaldehyde and permeabilized with $0.1 \%$ Triton X-100 before the incubation with Hoechst at the final concentration of $1 \mu \mathrm{g} / \mathrm{mL}$ for $10 \mathrm{~min}$. Then, the cells were washed three times with PBS and observed under fluorescent microscope (Leica). The fluorescence intensity was quantified using Image J software.

\subsection{Propidium Iodide-Cell Staining}

After treatments, $2,5 \times 10^{5}$ cells were collected and resuspended in $500 \mu \mathrm{L}$ of $50-\mu \mathrm{g} / \mathrm{mL}$ propidium iodide (PI) solution and incubated in the dark for $30 \mathrm{~min}$. After this time, samples were analyzed by acquired on a FACS-Calibur flow cytometer using the Cell Quest software (Becton Dickinson, 
Franklin Lakes, NJ, USA). The analysis of sub-G1 variation was performed using ModFitLT version 3 software (Verity).

\subsection{Western Blotting Analysis}

Pelleted cells were lysed in 3-5 volume of RIPA Buffer (R0278, Sigma-Aldrich), containing Protease Inhibitor Cocktail (P8340, Sigma-Aldrich) and Phosphatase Inhibitor Cocktail (P2850, Sigma-Aldrich). After centrifugation, supernatant phase was collected and underwent to protein content quantification by Bradford Assay (39222.02, Serva, Rome, Italy). An equal protein amount from each sample was diluted in Laemmli buffer 4X (S3401, Sigma-Aldrich), and finally boiled $5 \mathrm{~min}$ at $95^{\circ} \mathrm{C}$. Successively, polyacrylamide gels (10687.02, Serva) were loaded with 20-40 $\mu \mathrm{g}$ of whole extracts and SDS-PAGE was started. Using Mini Trans-Blot (Bio-Rad Laboratories), separated proteins were moved to nitrocellulose membranes (GE10600008 Sigma-Aldrich), which were finally blocked one hour in no-fat milk 5\% w/v to prevent nonspecific antibody bindings. After overnight incubation in primary antibody, membranes were washed in TBS Tween-20 (TC287, HIMEDIA) three times prior to and following conjugated secondary antibody ligation. Horseradish Peroxidase-mediated light reaction was made by enhanced chemiluminescence detection kit (EuroClone) and detected with Chemi Doc XRS (Bio-Rad).

\subsection{Detection of Intracellular ROS}

Intracellular ROS were detected by means of an oxidation-sensitive fluorescent probe $2^{\prime}, 7^{\prime}$-dichlorofluorescin diacetate (DCFH-DA) as previously reported [41]. Cells were grown in 12-well plates $\left(2.5 \times 10^{6}\right.$ cell/well), pre-incubated with DCFH-DA for $30 \mathrm{~min}$ and then incubated with protein samples for $24 \mathrm{~h}$. Control experiments were performed using untreated cells and cells exposed to a 0.001- $\mathrm{M} \mathrm{H}_{2} \mathrm{O}_{2}$. After incubation, cells were washed twice with PBS buffer and then lysed with Tris- $\mathrm{HCl} 0.5 \mathrm{M}, \mathrm{pH} 7.6,1 \%$ SDS. The non-fluorescent DCFH-DA is converted, by oxidation, to the fluorescent molecule $2^{\prime}, 7^{\prime}$-dichlorofluorescein (DCF). DCF fluorescence intensity was quantified on a PerkinElmer Life Sciences LS 55 spectrofluorometer using an excitation wavelength of $488 \mathrm{~nm}$ and an emission wavelength of $530 \mathrm{~nm}$. Data are expressed as average \pm S.D. from five independent experiments carried out in triplicate.

\subsection{Statistical Analysis}

Experimental results were subjected to rigorous statistical analysis. In details, student's $t$-distribution and one-way analysis of variance (ANOVA) were employed to calculate the significance in means between treated vs untreated groups and among different experimental groups, respectively. $p$-values of less than 0.05 were recognized as significant and indicated with graphic star as follows: ${ }^{*}: p<0.05 ;{ }^{* *}: p<0.01$; ${ }_{* * *} p<0.001$. All densitometric analyses were performed by Image J (NIH, Bethesda).

\section{Results}

\subsection{Vanillin Strongly Reduces Doxo-Induced Toxicity in H9C2 Cells}

In order to evaluate the potential vanillin cardioprotective properties in response to doxo treatment, first, we assessed the relative doxo-induced cytotoxicity in our experimental settings. According to previous findings, $\mathrm{H} 9 \mathrm{c} 2$ cardiac cells were exposed for $24 \mathrm{~h}$ to increasing concentration of doxo (from 0.1 up to $20 \mu \mathrm{M}$ ) and then cell viability was evaluated by MTT assay [28]. As shown in Figure 1A, up to $0.5-\mu \mathrm{M}$ doxo no significant changes were detected in cell viability, whereas a reduction of $20 \%$ and $35 \%$ was observed in response to 1 and $10-\mu \mathrm{M}$ doxo, respectively. Lastly, a further decrease up to $55 \%$ was monitored upon $20-\mu \mathrm{M}$ doxo exposure. To note, no cytotoxicity was observed in response to vanillin alone (Figure 1B). 


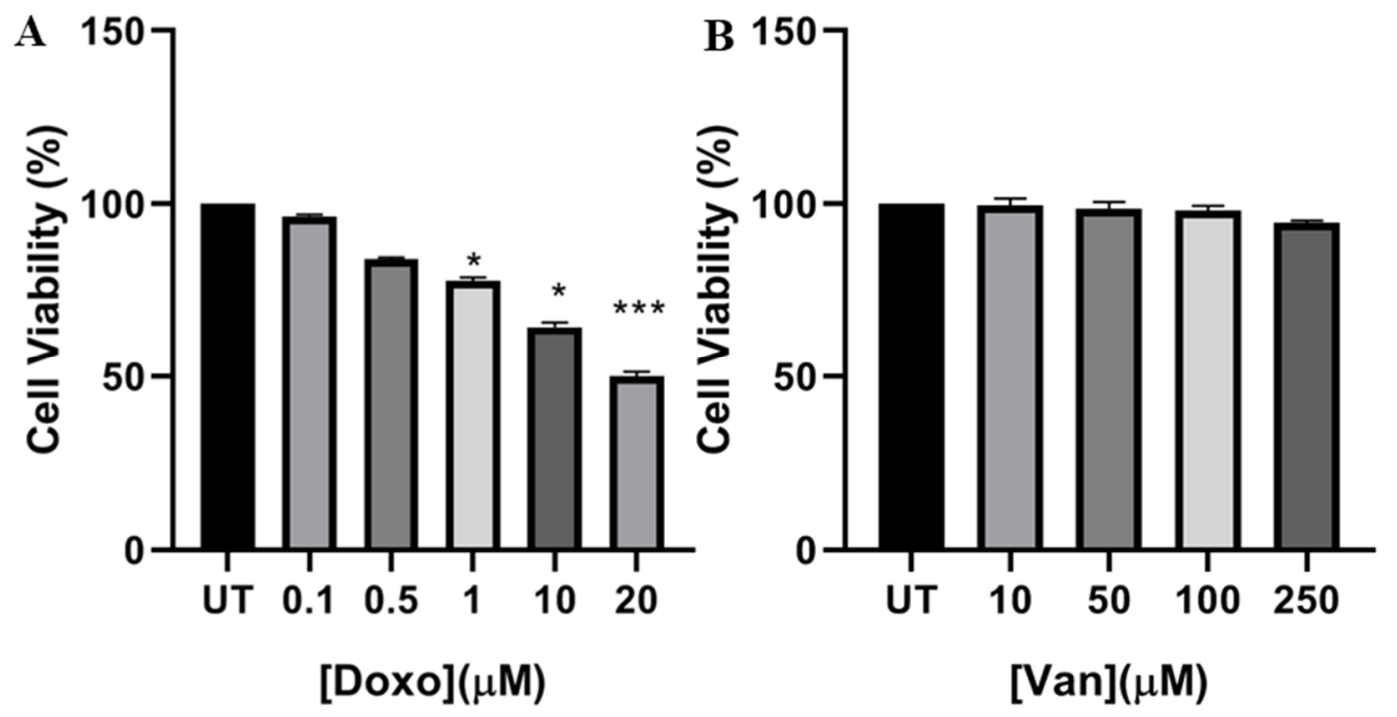

Figure 1. Effect of doxo and vanillin on cell viability. Cell viability was evaluated by MTT assay in $\mathrm{H} 9 \mathrm{c} 2$ cells exposed for $24 \mathrm{~h}$ to (A) increasing concentration of doxo (from 0.1 to $20 \mu \mathrm{M}$ ) and to (B) different concentrations of vanillin $(20,50,100$ and $150 \mu \mathrm{M}) \mathrm{UT}$ - untreated cells. Data are expressed as average percentage of MTT reduction \pm SD relative to untreated cells from triplicate wells from 5 separate experiments. ${ }^{*}: p<0.05 ;{ }^{* * *}: p<0.001$ by unpaired $t$-test. Other experimental details are described in Materials and Methods section.

Based on the above results, we decided to expose H9c2 cells to $20-\mu \mathrm{M}$ doxo, a very high concentration, with the aim of investigating the possible protective effect of vanillin in presence of doxo-dependent incisive and forceful cell damage conditions. In details, H9c2 cells were pretreated and not with different concentrations of vanillin $(20,50,100$ and $150 \mu \mathrm{M})$ for $18 \mathrm{~h}$ and then exposed to doxo administration for additional $24 \mathrm{~h}$. Even though in the pretreated samples with 20 and $50-\mu \mathrm{M}$ vanillin doxo provoked a comparable cytotoxicity; interestingly, the usage of 100 and $150-\mu \mathrm{M}$ vanillin significantly counteracted doxo-induced cell viability reduction (Figure 2A).

The plant-derived curcumin, whose vanillin is generated by degradation, has been demonstrated to possess similar cardioprotective feature only in pretreatment with doxo, whereas concomitant curcumin-doxo treatment potentiated the cardiotoxicity $[28,29]$. To figure out if vanillin had an analogous behavior when used in cotreatment with doxo, we evaluated the effects of concomitant vanillin-doxo treatment at the same time and doses already described for the pretreatment procedure. Figure $2 \mathrm{~B}$ shows that even in cotreatment, 100 and $150-\mu \mathrm{M}$ vanillin significantly prevented the doxo-induced toxicity in $\mathrm{H} 9 \mathrm{c} 2$ cells, further suggesting its possible cardioprotective role against doxo exposure. Based on these results, $20-\mu \mathrm{M}$ doxo and $100-\mu \mathrm{M}$ vanillin doses were chosen as working concentrations for all the subsequent experiments.

Moreover, phase-contrast microscopy analysis exhibited reduction in cell amount, modification in cell morphology and cell fragments appearance in reaction to doxo treatment, whereas both co- and pre-incubation with vanillin attenuated those qualitative and quantitative alterations (Figure 2C).

Overall, these data indicate that vanillin strongly reduces doxo-induced toxicity in $\mathrm{H} 9 \mathrm{c} 2$ cells. 
$\mathbf{A}$

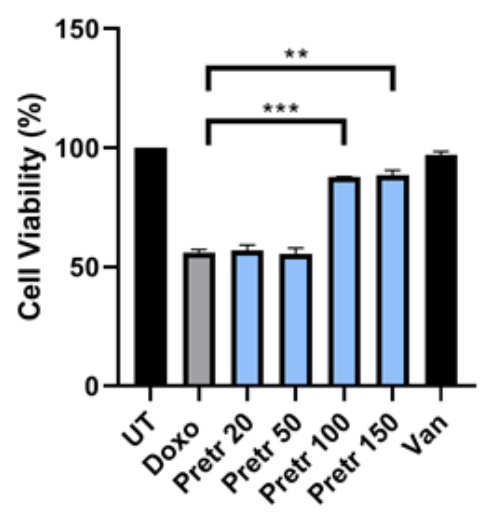

$[\mu \mathrm{M}]$
B

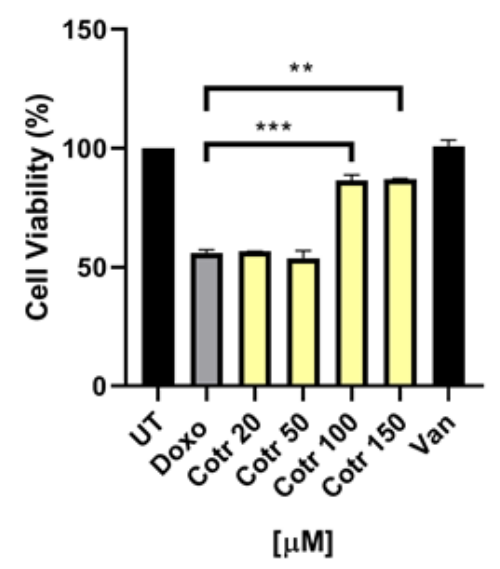

C

UT

Doxo

Pretr
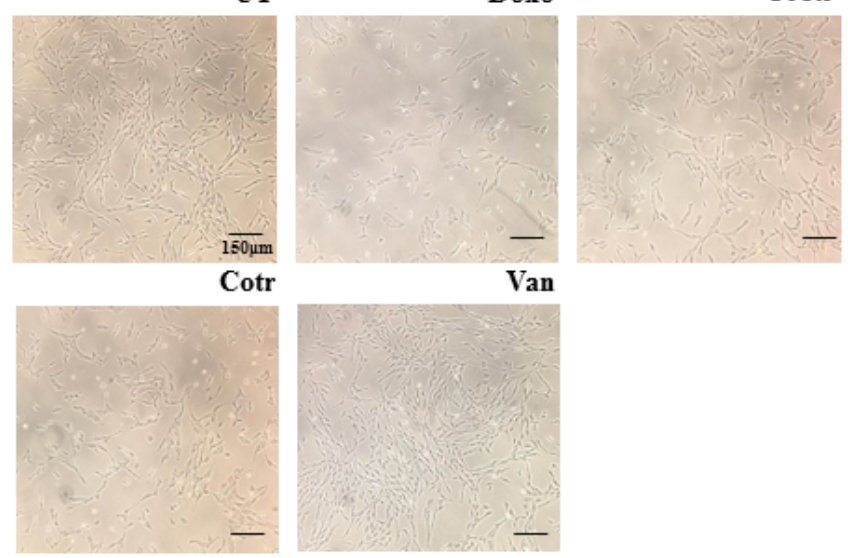

Figure 2. Effect of vanillin on doxo-induced cytotoxicity. Cell viability was evaluated by MTT assay in H9c2 cells exposed to doxo for $24 \mathrm{~h}$, (A) pretreated and (B) co-treated with vanillin at the indicated concentrations. Data are expressed as average percentage of MTT reduction \pm SD relative to untreated cells from triplicate wells from 5 separate experiments. UT-untreated cells; doxo-cells exposed to 20- $\mu \mathrm{M}$ doxo; Pretr-vanillin pretreated cells for $18 \mathrm{~h}$; Cotr-vanillin cotreated cells; Van: cells exposed to $150-\mu \mathrm{M}$ Van (C) Phase contrast microscopy images taken at the end of treatment time with a higher vanillin concentration. ${ }^{* *}: p<0.01{ }^{* * *}: p<0.001$ by one-way ANOVA. Other experimental details are described in Materials and Methods section.

\subsection{Vanillin Prevents Doxo-Induced Cell Damage and Death in H9C2 Cells}

To further investigate the protective vanillin effects in doxo-treated $\mathrm{H} 9 \mathrm{c} 2$ cells, we also measured the release of intracellular enzymes upon cell damage [42]. Specifically, we tested the activity of lactate dehydrogenase (LDH), aspartate aminotransferase (AST) and alanine aminotransferase (ALT) in the culturing medium of cells exposed for $24 \mathrm{~h}$ to doxo and vanillin, both as a single agent and in combination (pre- and cotreatment). As shown in Table 1, medium from cells treated with doxo revealed a clear increase in both LDH and AST activity compared to untreated cells, thus indicating their release in response to cell membrane injury. Interestingly, the presence of vanillin, both in pre- and cotreatment conditions, completely abrogated the doxo-mediated AST increase and strongly reduced LDH activity compared to doxo alone. According to the non-functional role in the cardiac system and to its reduced expression in this body compartment, no ALT activity variations were detected in each tested sample [43].

In agreement with these observations, were those obtained evaluating the number of dead cells by Trypan Blu Assay. H9c2 cells were exposed for $24 \mathrm{~h}$ to doxo in the absence and presence of vanillin, 
both in pre- and cotreatment conditions, after which, blue dead cells were counted and discriminated by living cells. Figure $3 \mathrm{~A}$ shows that in reaction to doxo administration more than $10^{5}$ dead cells were detected, whereas in the presence of vanillin a strong reduction in dead cells was observed (approximately 50\% respect to cells treated with only doxo). Additionally, the beneficial vanillin effects were also observed by nuclear DAPI staining (Figure 3B).

A

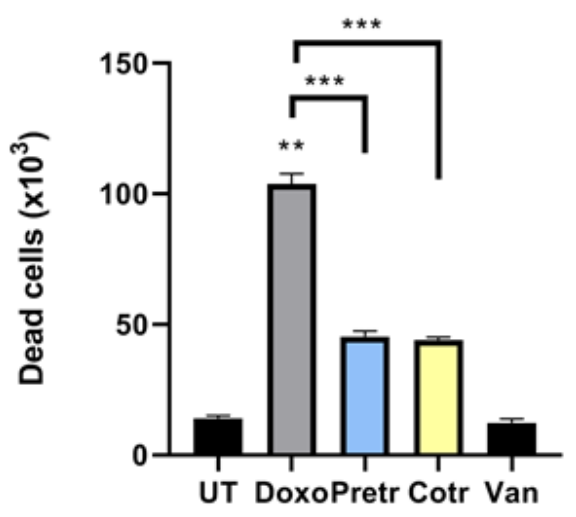

B
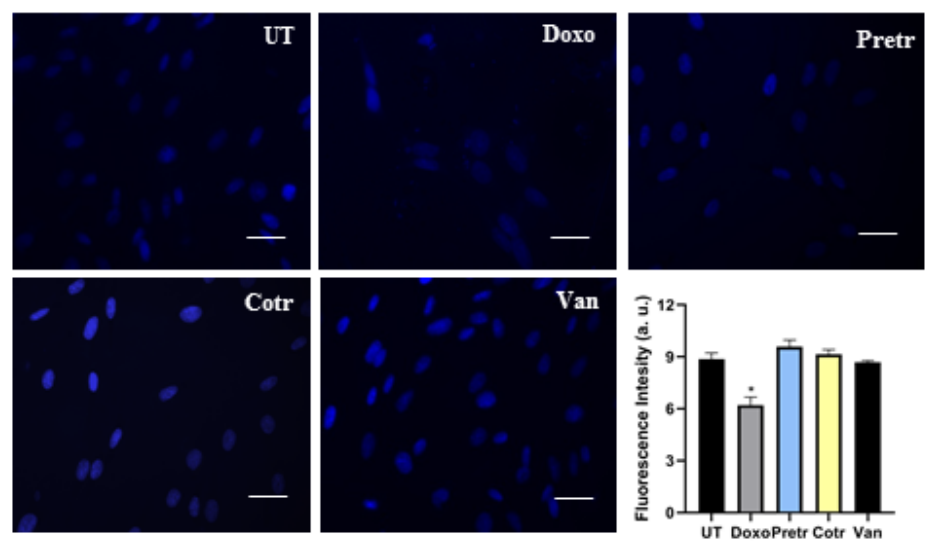

Figure 3. Effect of vanillin on doxo-induced cell death and nuclear alteration. (A) Dead cells number were evaluated by Trypan Blue assay in H9c2 cells exposed to $20 \mu \mathrm{M}$ doxo for $24 \mathrm{~h}$, pretreated (Pretr) and co-treated (Cotr) with 100- $\mu \mathrm{M}$ vanillin. UT-untreated cells; doxo-cells exposed to 20- $\mu \mathrm{M}$ doxo; Van-cells exposed to 100- $\mathrm{MM}$ Van. Scale bar represents $50 \mu \mathrm{m}$. Data represent the average of three independent experiments $\pm \mathrm{SD}$; (B) representative fluorescence images of cells stained by DAPI nuclear staining. The fluorescence intensity was estimated by Image J software. *: $p<0.05$; ${ }^{* *}: p<0.01{ }^{* * *}: p<0.001$ by two-way ANOVA. Other experimental details are described in Materials and Methods section.

According to previous findings, untreated cells were observed as round-shaped nuclei with homogeneous fluorescence intensity, whereas doxo treatment induced nuclear morphologic alterations. Conversely, in both experimental conditions in which vanillin was used in combination with doxo, nuclear integrity is maintained.

Taken together, this evidence indicates that vanillin strongly reduces doxo-induced cell damage and death in $\mathrm{H} 9 \mathrm{C} 2$ cells. 
Table 1. Effect of vanillin on doxo-induced cellular damage. The release of AST, ALT, LDH intracellular enzymatic activities was evaluated in cultured media of $\mathrm{H} 9 \mathrm{c} 2$ cells exposed to $20-\mu \mathrm{M}$ doxo for $24 \mathrm{~h}$, pretreated (Pretr) and cotreated (Cotr) with $100-\mu \mathrm{M}$ vanillin. Values are means \pm S.D. of triplicate samples of a typical experiment. Medium: cultured medium without cells; UT: untreated cells; doxo: cells exposed to doxo; Van: cells exposed to vanillin.

\begin{tabular}{lllll}
\hline Sample & (Protein) $(\mathrm{g} / \mathbf{d L})$ & LDH $(U / L)$ & AST (U/L) & ALT (U/L) \\
\hline Medium & $1.1 \pm 0.05$ & $40 \pm 0.01$ & $3 \pm 0.20$ & $6 \pm 0.01$ \\
UT & $1 \pm 0.04$ & $42 \pm 0.03$ & $3 \pm 0.10$ & $6 \pm 0.03$ \\
Doxo & $1.1 \pm 0.03$ & $212 \pm 0.02$ & $23 \pm 0.05$ & $6 \pm 0.10$ \\
Pretr & $1.1 \pm 0.03$ & $60 \pm 0.03$ & $3 \pm 0.10$ & $6 \pm 0.20$ \\
Cotr & $1.1 \pm 0.04$ & $62 \pm 0.05$ & $3 \pm 0.10$ & $6 \pm 0.05$ \\
Van & $1 \pm 0.02$ & $45 \pm 0.04$ & $3 \pm 0.20$ & $6 \pm 0.02$ \\
\hline
\end{tabular}

\subsection{Vanillin Reduces the doxo-Mediated Apoptosis in H9c2 Cells}

To further investigate the vanillin-mediated cell death reduction in response to doxo administration, cytofluorimetric analysis was also performed. Specifically, H9c2 cells were exposed for $24 \mathrm{~h}$ to doxo in the absence and presence of vanillin, both in pre- and cotreatment conditions; thereafter, PI-stained cells were analyzed by flow cytometry assay. As indicated in Figure 4, doxo exposure strongly increased the sub-G1 appearance (+17\%) compared to untreated cells, meanwhile this increment was markedly reduced in presence of vanillin (4\% in pretreated cells and $6 \%$ in cotreated cells).

A
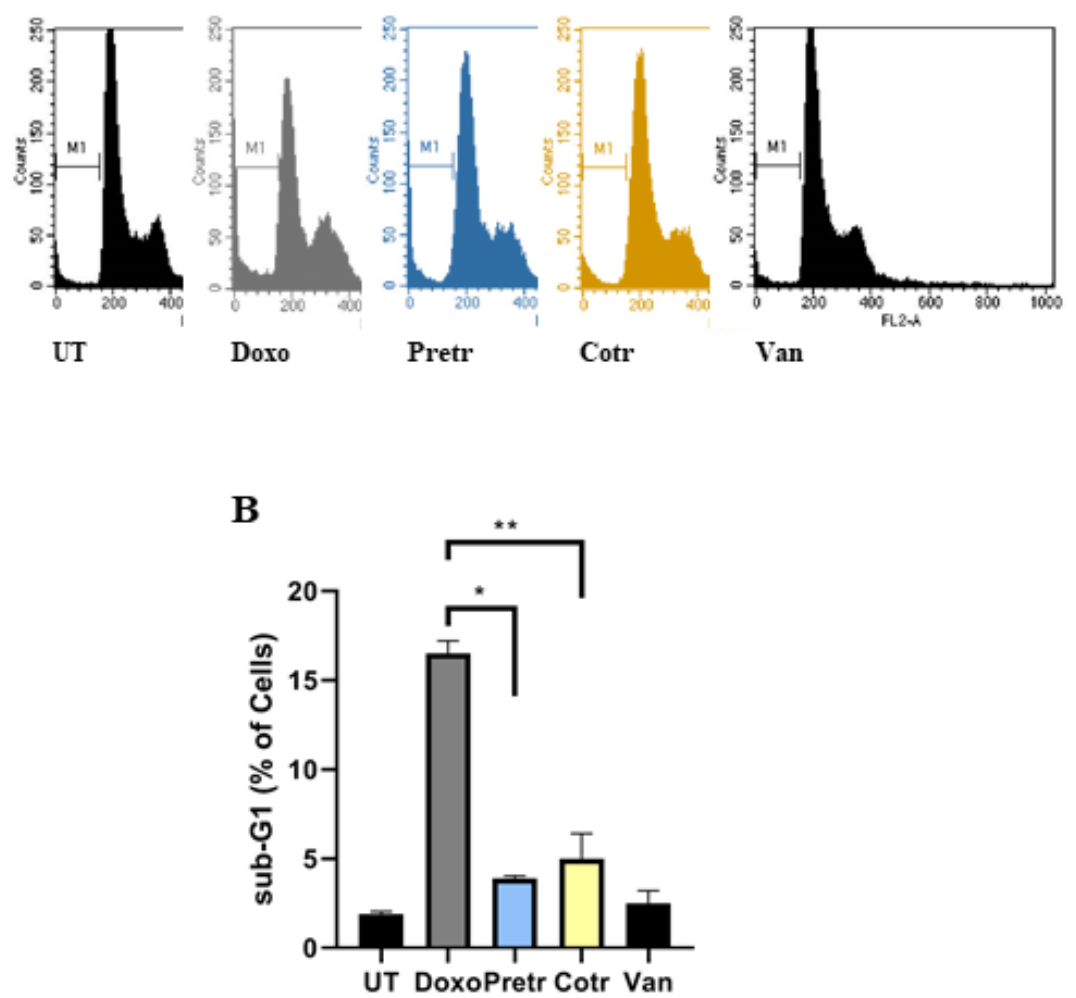

Figure 4. Effect of vanillin on doxo-induced sub G1-phase alteration. (A) Representative experiments of PI-stained H9c2 cells exposed to $20-\mu \mathrm{M}$ doxo for $24 \mathrm{~h}$, pretreated (Pretr) and co-treated (Cotr) with $100-\mu \mathrm{M}$ vanillin. UT-untreated cells; doxo-cells exposed to $20-\mu \mathrm{M}$ doxo; Van—cells exposed to 100- $\mu \mathrm{M}$ Van; (B) sub-G1 phase quantification of not less than two. Data represent the average of three independent experiments \pm SD. ${ }^{*}: p<0.05 ;{ }^{* *}: p<0.01$ by one-way ANOVA. Other experimental details are described in Materials and Methods section. 
It has been reported that doxo can induce cell death by necrosis, autophagy or apoptosis in cardiomyocytes [5]. Since sub-G1 population represents the proportion of cells having undergone DNA fragmentation, one of the biochemical hallmarks of apoptosis, we also assessed the levels of some proteins involved in apoptosis in our specific conditions. To this purpose, $\mathrm{H} 9 \mathrm{c} 2$ cells were treated in the same experimental conditions already described in Figure 4 except that, at the end of each experiments, cell extracts were prepared and analyzed by western blotting for cleaved caspase-3 (CC3), total PARP and its cleaved form (c-PARP). According to the sub-G1 data, in the samples exposed to only doxo, an increase in cleaved form of caspase-3 and PARP1 was detected. Interestingly, in the presence of vanillin, both in pre- and cotreatment, a strong reduction in the caspase- 3 and PARP1 activation were observed (Figure 5). All together, these data suggest that vanillin is able to counteract the doxo-induced cell death, reducing its apoptosis induction in $\mathrm{H} 9 \mathrm{c} 2$ cells.

A
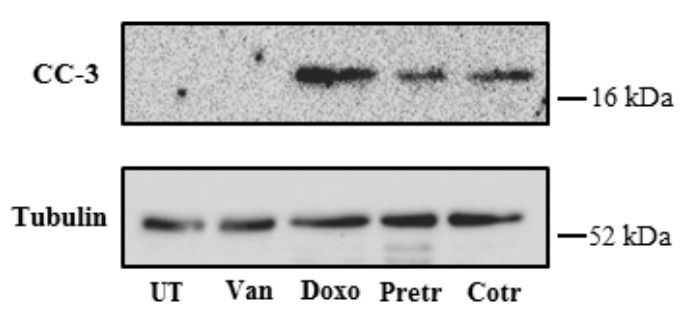

B

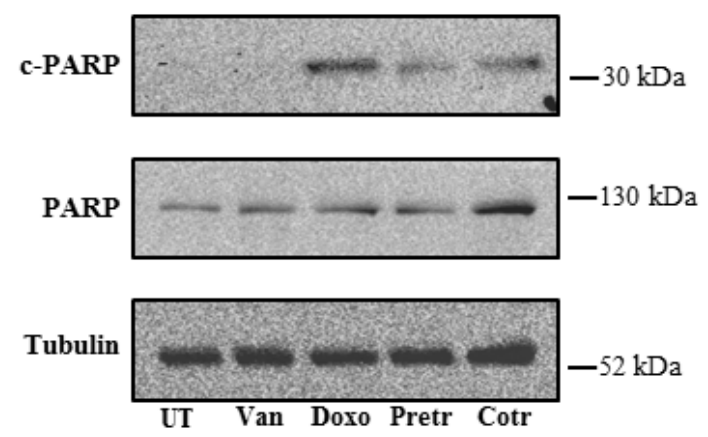

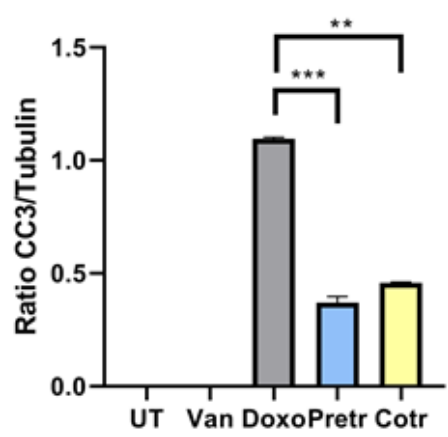

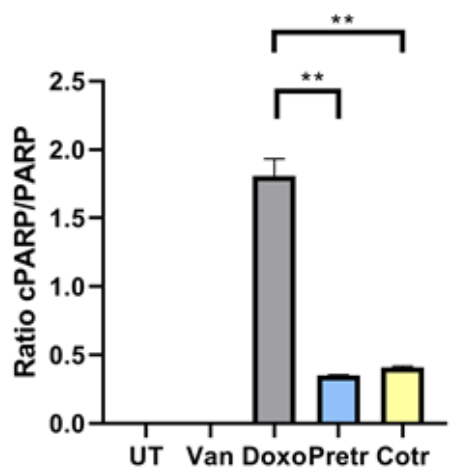

Figure 5. Effect of vanillin on caspase 3 and PARP1 activation. (A) Western blot analysis of cleaved caspase-3 (CC3) (A), PARP1 and cleaved PARP1 (c-PARP) (B) in H9c2 cells exposed to 20- $\mu \mathrm{M}$ doxo for $24 \mathrm{~h}$, pretreated (Pretr) and cotreated (Cotr) with 100- $\mu \mathrm{M}$ vanillin. UT—untreated cells; doxo-cells exposed to 20- $\mu \mathrm{M}$ doxo; Van-cells exposed to 100- $\mu \mathrm{M}$ Van. Images are representative of western blotting from two different cellular extract with similar results. Data represent the average of three independent experiments $\pm \mathrm{SD}$. ${ }^{* *}: p<0.01 ; * * *: p<0.001$ by one-way ANOVA. Other experimental details are described in Materials and Methods section.

\subsection{Vanillin Prevents Doxo-Induced ROS Production and ERK1/2 Activation in H9c2 Cells}

Oxidative stress induction and a life-threatening ROS production represent the main mechanism by which doxo generally induces cardiotoxicity [7]. In the same way, vanillin exerts its beneficial properties exactly providing an antioxidant action $[37,39,44]$. With the purpose of investigating the molecular mechanism associated with the beneficial effect of vanillin in preventing doxo-induced cardiotoxicity, we analyzed the ability of vanillin to affect the oxidative stress in $\mathrm{H} 9 \mathrm{c} 2$ cells exposed to 
doxo. For this reason, intracellular ROS levels in H9c2 cells exposed to doxo for $24 \mathrm{~h}$ in the absence and presence of vanillin were measured by DCFH-DA fluorescence assay (Figure 6A). As expected, upon doxo treatment, an increase of intracellular ROS production was detected, as indicated by the increase in the DCF fluorescence. Interestingly, both the pre- and cotreatment with vanillin strongly reduced the ROS production that was similar to untreated cells.

A
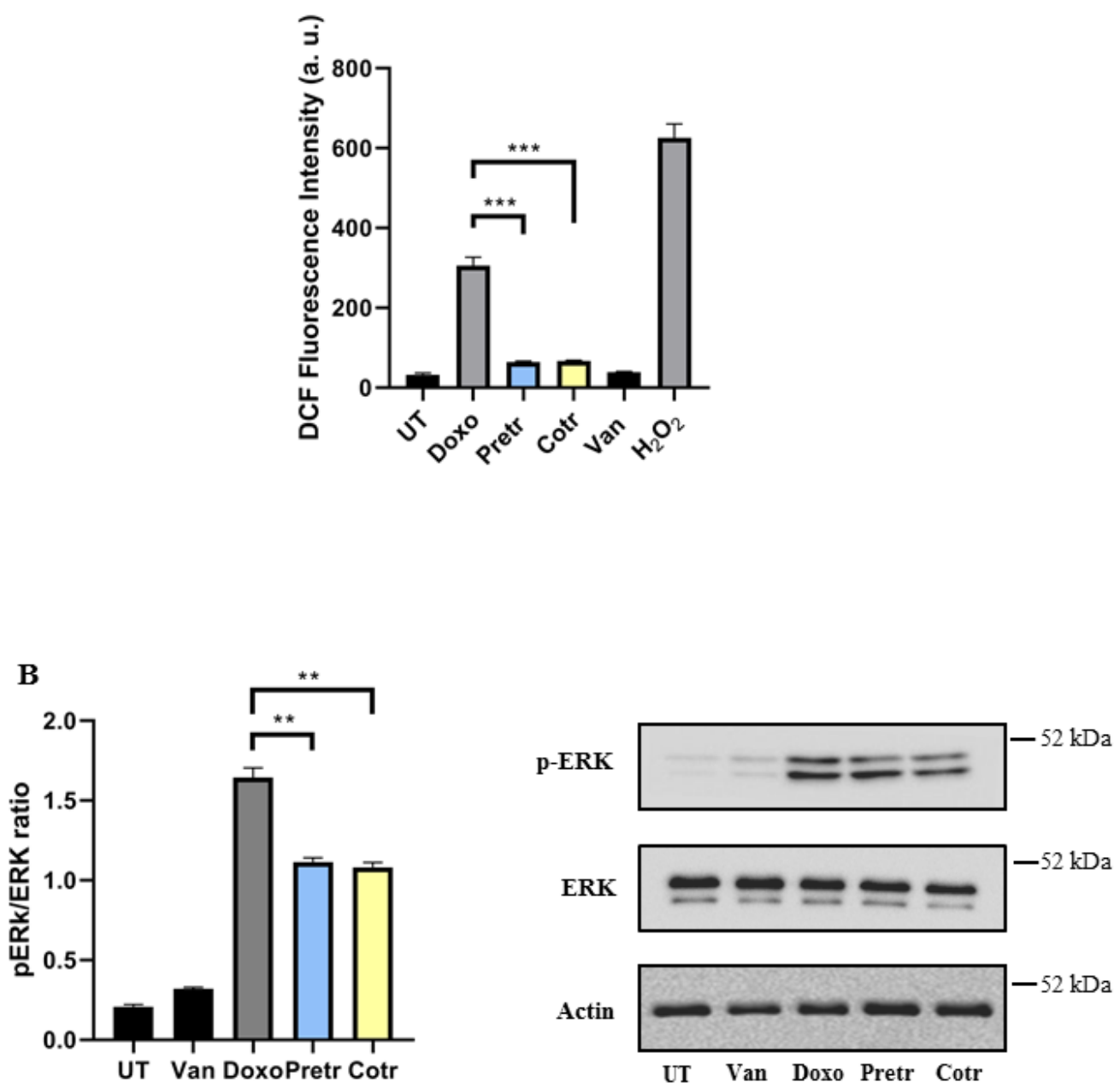

Figure 6. Effect of vanillin on doxo-induced ROS production and MAPK signaling. (A) ROS production was evaluated by DCFHDA assay in $\mathrm{H} 9 \mathrm{c} 2$ cells exposed to $20-\mu \mathrm{M}$ doxo for $24 \mathrm{~h}$, pretreated (Pretr) and co-treated (Cotr) with $100-\mu \mathrm{M}$ vanillin. The data are presented as mean $\pm \mathrm{SD}$ of three replicates in five independent experiments; (B) western blot analysis of ERK activation. The image is representative of western blotting from two different cellular extract with similar results. UT-untreated cells; doxo-cells exposed to 20- $\mu \mathrm{M}$ doxo; Van—cells exposed to 100- $\mu \mathrm{M}$ Van; $\mathrm{H}_{2} \mathrm{O}_{2}$-cells treated with $1-\mathrm{mM} \mathrm{H}_{2} \mathrm{O}_{2} ;{ }^{* *} p<0.01 ;{ }^{* * *} p<0.001$, by one-way ANOVA. Other experimental details are described in Materials and Methods section.

MAPKs signaling cascade is a downstream event of ROS production, deeply involved in cell proliferation and apoptosis [45]. It has been reported that MAPK signaling pathway is involved in the doxo-induced cardiotoxicity, via phosphorylation of ERK1/2 [46,47]. For this reason, we evaluated the ERK1/2 activation in H9c2 cells exposed to doxo in the absence and presence of vanillin by western blot analysis. As displayed in Figure 6B, doxo treatment induced a strong increase in ERK1/2 phosphorylation, without significant variations in total amount. Intriguingly, in $\mathrm{H} 9 \mathrm{C} 2$ cells pre- and cotreated with vanillin, a substantial decrease of the phospho-ERK1/2 intensity was detected. 
Overall, these results suggest that the protective effect of vanillin against the doxo-induced cardiotoxicity could be mediated by its antioxidant activity, likely affecting ROS production and ROS-related pathways, such as ERK1/2.

\subsection{Vanillin Does Not Impair Antitumor doxo Activity in U2OS Osteosarcoma Cells}

In spite of the copious number of treatment-related side effects, some of them potentially lethal such as the delayed cardiotoxicity already discussed, doxo still remains the elective standard of care for several tumor types, including breast cancer and osteosarcoma [48,49]. Aiming to highlight the scientific relevance of the emerging vanillin cardioprotective skills in reaction to doxo administration, and concomitantly to exclude any possible impairment of vanillin on doxo antitumor activity, we also evaluated the effects of vanillin, doxo and their combinations in a widely used osteosarcoma cell model [50]. In detail, U2OS cells were treated in the same experimental conditions (time and doses) previously described for $\mathrm{H} 9 \mathrm{c} 2$ cells and then evaluated for live and dead cells amount. As extensively predicable, Figure 7 shows that doxo dramatically decreased the relative number of live cells $(-43 \%)$ and subsequently increased the percentage of dead cell $(+22 \%)$, whereas vanillin did not affect both live and dead cells compare to control. Interestingly, although no significant additive or synergistic effects seem to become known from the evaluation of those biologic parameters, both combinatory treatments caused live cells reduction and cell death increase comparable to doxo alone.

A

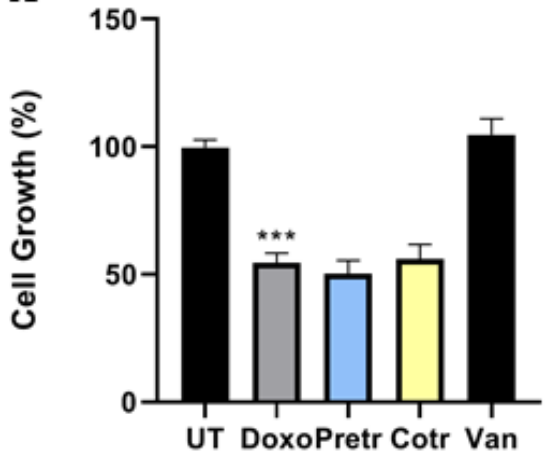

B

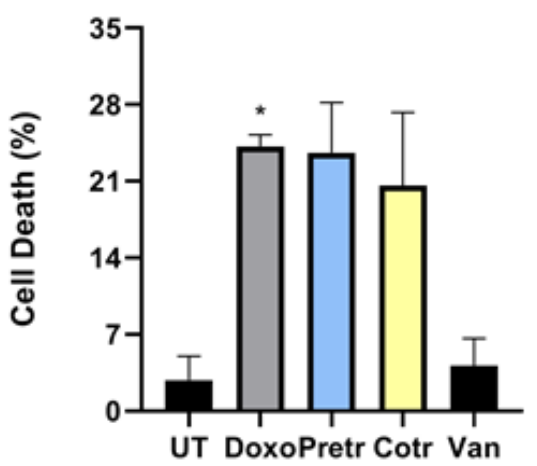

Figure 7. Effect of vanillin on doxo-induced antineoplastic properties in U2OS osteosarcoma cells. Number of living (A) and dead (B) U2OS cells exposed to 20- $\mu \mathrm{M}$ doxo for $24 \mathrm{~h}$, pretreated (Pretr) and cotreated (Cotr) with $100-\mu \mathrm{M}$ vanillin. UT-untreated cells; doxo-cells exposed to $20-\mu \mathrm{M}$ doxo; Van-cells exposed to $100-\mu \mathrm{M}$ Van; ${ }^{*} p<0.05 ;{ }^{* * *} p<0.001$ by one-way ANOVA.

Overall, this evidence indicates that vanillin does not impair doxo-mediated antineoplastic features in U2OS osteosarcoma cells.

\section{Discussion}

Despite of the potentially lethal delayed cardiotoxicity, doxo still remains the elective standard of care for several tumor in which no target therapy has been recognized yet [48,49]. Unfortunately, the only FDA approved cardioprotective agent (dexrazoxane) showed a limited application due to its interference with doxo efficacy, leading to secondary malignancies [9,51]. Therefore, reducing the doxo-related cardiac injuries are absolutely needed in order to extend the duration of action, and consequently to increase the doxo antitumor efficacy.

Several plant-derived polyphenols have drawn attention in pharmaceutical field thanks to their ability to reduce oxidation species synthesis and accumulation in human body $[5,20,21,52,53]$. Recently, it was reported that curcumin is able to ameliorate the doxo cardiotoxic effect in vitro and in vivo [22,24]. However, curcumin potential clinical application both as chemotherapeutic and cardioprotective agent remains constrained due to its poor bioavailability and low aqueous 
solubility [30,33]. In our previous study, we reported that curcumin and vanillin, one of the main and stable curcumin-derived degradation products, have similar effects on anti-amyloid as well as anti-AGEs formation in insulin, supporting the hypothesis that vanillin could mediate some of the biologic properties ascribed to curcumin [44]. In the present study, we demonstrated that vanillin significantly ameliorates the doxo-induced toxicity in H9c2 cells. Specifically, vanillin was able to largely restore the cell viability and damage in reaction to doxo exposure, as indicated by the reduction of the LDH and AST intracellular enzymatic release. According to these results, a strongly reduction in cell death and an attenuation of nuclear shrinkage and deformity were also induced by vanillin in presence of doxo treatment.

As largely known, doxo-induced cardiomyopathy is due to several mechanisms, including increased oxidative stress, lipid peroxidation, DNA damage, apoptosis and, more recently, autophagy [5]. However, ROS overproduction and apoptosis remain the hallmark of the doxo cardiotoxicity $[3,5-8,54]$. In agreement with these evidences, our results show that in the presence of vanillin a strong reduction of sub-G1 phase occurred, thus suggesting that vanillin is able to counteract the doxo-induced apoptosis. Accordingly, we observed a strong increase of cleaved caspase- 3 and PARP1, two of the main markers of apoptosis, in response to doxo, that was prevented by vanillin. BAX activation has recently been indicated as rate-limiting step in doxorubicin-induced cardiomyopathy [55]. Similarly, vanillin has also been reported to modulate Bcl-2-associated X protein positively and negatively in reaction to discrete stimuli [56,57]. Therefore, we cannot exclude that other apoptotic-related proteins are involved in the vanillin-mediated cardioprotective effects in $\mathrm{H} 9 \mathrm{c} 2$ cells. Moreover, data obtained by DCFH assay also indicate that vanillin-inhibited ROS production induced by doxo through its antioxidant activity.

The regulation of downstream pathways in response to doxo-induced ROS production could have an important role to inhibit doxo-induced toxicity. It is well-known that MAPK cascade is involved in the response to doxo-induced oxidative stress. In particular, ERKs proteins are known to be activated by doxo in H9c2 cells [46,47]. In this respect, Huang et al. has recently proved that doxo induced mitochondrial ROS release, ERK activation and HSF2-mediated AT $1 \mathrm{R}$ upregulation, causing heart failure in vitro and in vivo models [58]. Based on these considerations, we detected a significant attenuation of ERK phosphorylation in presence of vanillin compared to that observed in response to doxo alone. These results suggest that vanillin could protect from doxo-induced cardiotoxicity affecting the MAPK cascade, through the modulation of the ERK activation. Although not in reaction to doxo administration, a similar vanillin-mediated signaling modulation has been reported by Dhanalakshmi and co-workers who, studying the rotenone-induced neurotoxicity in SH-SY5Y neuroblastoma cells, observed an attenuation in rotenone-induced ERK phosphorylation as a consequences of vanillin pretreatment [38]. Furthermore, even in AOM/DSS-induced colitis-associated mouse model vanillin prevents the colon cancer development weakening the NF-KB and ERK AOM/DSS-mediated activation [59]. The ability of vanillin to modulate the MAPK pathways, such as ERKs, p38 and JNKs, has also been reported in different models. Cheng and coworkers, for instance, have shown that vanillin-inhibited activator protein 1 (AP-1) in a dose-dependent manner via ERK in hepatocellular carcinoma cell line HepG2 [60].

Since curcumin showed cardioprotective properties only when used in pretreatment, but not in concomitant curcumin-doxo treatment, where instead synergistic effects were observed, we also addressed this issue analyzing both of those conditions for the entire study [28,29]. Irrespective of the administration modalities, pre- and cotreatment, we observed that vanillin attenuates doxo-induced cardiotoxicity in $\mathrm{H} 9 \mathrm{c} 2$ cells. In reliance on this evidence, it can be deduced that vanillin is partially implicated in the curcumin-mediated cardioprotective features, but probably other curcumin-derived degradation products may be involved in. It remains unclear how the same compounds are capable of inducing opposite cardiac effects simply by changing the experimental conditions anyway.

Vanillin antioxidant and anticancer potential have extensively been described in different cancer preclinical models, such as breast, ovarian, cervical and colon cancer [37]. More recently, discrete antitumor effects have also been reported in lung, hepatocyte and neuroblastic cells. In this 
respect, Srinual and coworkers have established that vanillin suppresses cancer stemness phenotypes in the human non-small cell lung cancer NCI-H460 cell line through the downregulation of CD133 and ALDH1A1 and the associated transcription factors, Oct4 and Nanog [61]. Furthermore, in human hepatocyte carcinoma and neuroblastoma models the antioxidant properties are strictly related to the vanillin-mediated antineoplastic efforts, because it significantly reduces the mitochondrial membrane depolarization and ROS production, leading to apoptosis induction [62]. Taking into consideration this evidence and in light of the cardioprotective results shown in the present study, it is conceivable to develop a therapeutic regimen in which vanillin is used either as adjuvant chemotherapy agent or just heart injury defending compound. Speaking of which, a recent study reported that vanillin enhances doxo-mediated antiproliferative effects in different in vitro and in vivo breast cancer models, therefore suggesting a potential synergistic outcome [63]. Although our preliminary findings do not reveal any vanillin-mediated cytotoxic activities in U2OS osteosarcoma cells, the doxo efficacy does not seem to be hindered by the vanillin. However, further and more comprehensive studies, are required to fully define the vanillin role in osteosarcoma. It should be clarified that this interesting aspect does not represent the aim of the current study, even though it may portray our future investigation however.

In conclusion, our study indicates for the first time that vanillin is able to protect cardiomyocytes against doxo-induced cell injury. The overall data suggest that the main mechanism by which vanillin exerts its beneficial effect could be ascribed to their antioxidant properties. The inhibition of ROS production impairs the MAPK signaling thus affecting the apoptotic cell death. Despite the high doses generally employed in both in vitro and in vivo studies, vanillin shows a very wide safety profile, without any toxic effects on kidney, liver and brain tissues $[37,63,64]$. In agreement with the existing findings, we used vanillin in $\mu \mathrm{M}$ range whereas a doxo overdose has been applied with the purpose of exploring the vanillin-mediated protective effects in the event of deep cell damage. Even though the present study clearly demonstrates the biologic effect of vanillin in doxo-induced cardiotoxicity, the mechanisms underlying the observed protective outcome is only brushed. Moreover, extending our contribution to additional in vitro and in vivo models could further increase the clinical repercussion of these findings. In conclusions, our findings open new avenues for developing therapeutic applications for vanillin in order to counteract the anthracycline related cardiotoxicity and improving the long-term outcome of antineoplastic treatment.

Author Contributions: Conceptualization, I.S., L.S., S.N. and M.B.; methodology, I.S., L.S., S.N. and M.B.; investigation, L.S., A.R., M.B.; Data analysis and interpretation, I.S., L.S., S.N. and M.B.; writing-original draft preparation, I.S., L.S. and M.B.; writing-review \& editing, I.S., L.S., S.N. and M.B.; visualization, C.I.; supervision, D.B., A.G.; funding acquisition, C.I. All authors have read and agreed to the published version of the manuscript.

Funding: This work was supported by grant from Italian Ministry of University and Research, Program “Giovani Ricercatori RitaLeviMontalcini".

Conflicts of Interest: The authors declare no conflict of interest.

\section{References}

1. Tacar, O.; Sriamornsak, P.; Dass, C.R. Doxorubicin: An update on anticancer molecular action, toxicity and novel drug delivery systems. J. Pharm. Pharmacol. 2013, 65, 157-170. [CrossRef] [PubMed]

2. Kaviyarasi, R.; Abilash, V.G.; Turupathi, P.P.B.; Sankarganesh, A. Molecular mechanism of doxorubicin -induced cardiomyopathy-An update. Eur. J. Pharmacol. 2018, 818, 241-253. [CrossRef]

3. Chatterjee, K.; Zhang, J.; Honbo, N.; Karliner, J.S. Doxorubicin cardiomyopathy. Cardiology 2010, 115, $155-162$. [CrossRef] [PubMed]

4. Li, J.; Chang, H.; Banchs, J.; Araujo, D.M.; Hassan, S.A.; Wagar, E.A.; Yeh, E.T.H.; Meng, Q.H. Detection of subclinical cardiotoxicity in sarcoma patients receiving continuous doxorubicin infusion or pre-treatment with dexrazoxane before bolus doxorubicin. Cardiooncology 2020, 6, 1. [CrossRef]

5. Shabalala, S.; Muller, C.J.F.; Louw, J.; Johnson, R. Polyphenols, autophagy and doxorubicin-induced cardiotoxicity. Life Sci. 2017, 180, 160-170. [CrossRef] [PubMed] 
6. Menna, P.; Paz, O.G.; Chello, M.; Covino, E.; Salvatorelli, E.; Minotti, G. Anthracycline cardiotoxicity. Expert Opin. Drug Saf. 2012, 11, S21-S36. [CrossRef] [PubMed]

7. Angsutararux, P.; Luanpitpong, S.; Issaragrisil, S. Chemotherapy-Induced Cardiotoxicity: Overview of the Roles of Oxidative Stress. Oxid. Med. Cell. Longev. 2015, 2015, 795602. [CrossRef] [PubMed]

8. Wu, J.; Guo, W.; Lin, S.Z.; Wang, Z.J.; Kan, J.T.; Chen, S.Y.; Zhu, Y.Z. Gp130-mediated STAT3 activation by S-propargyl-cysteine, an endogenous hydrogen sulfide initiator, prevents doxorubicin-induced cardiotoxicity. Cell Death Dis. 2016, 7, e2339. [CrossRef] [PubMed]

9. Aleksandar, P.; Dragana, M.Ć.; Nebojša, J.; Biljana, N.; Nataša, S.; Branka, V.; Jelena, K.V. Wild edible onions-Allium flavum and Allium carinatum—successfully prevent adverse effects of chemotherapeutic drug doxorubicin. Biomed. Pharmacother. 2019, 109, 2482-2491. [CrossRef]

10. Li, T.; Singal, P.K. Adriamycin-induced early changes in myocardial antioxidant enzymes and their modulation by probucol. Circulation 2000, 102, 2105-2110. [CrossRef]

11. Cappetta, D.; De Angelis, A.; Sapio, L.; Prezioso, L.; Illiano, M.; Quaini, F.; Rossi, F.; Berrino, L.; Naviglio, S.; Urbanek, K. Oxidative Stress and Cellular Response to Doxorubicin: A Common Factor in the Complex Milieu of Anthracycline Cardiotoxicity. Oxid. Med. Cell. Longev. 2017, 2017, 1521020. [CrossRef] [PubMed]

12. Piepoli, M.F.; Hoes, A.W.; Agewall, S.; Albus, C.; Brotons, C.; Catapano, A.L.; Cooney, M.T.; Corrà, U.; Cosyns, B.; Deaton, C.; et al. ESC Scientific Document Group. European guidelines on cardiovascular disease prevention in clinical practice: The Sixth Joint Task Force of the European Society of Cardiology and Other Societies on Cardiovascular Disease Prevention in Clinical Practice (constituted by representatives of 10 societies and by invited experts) developed with the special contribution of the European Association for Cardiovascular Prevention \& Rehabilitation (EACPR). Eur. Heart J. 2016, 37, 2315-2381. [CrossRef] [PubMed]

13. Chang, H.M.; Moudgil, R.; Scarabelli, T.; Okwuosa, T.M.; Yeh, E.T.H. Cardiovascular Complications of Cancer Therapy: Best Practices in Diagnosis, Prevention, and Management: Part 1. J. Am. Coll. Cardiol. 2017, 70, 2536-2551. [CrossRef] [PubMed]

14. Korzeniowska, K.; Jankowski, J.; Cieślewicz, A.; Jabłecka, A. Is it possible to prevent chemotherapy-induced heart failure with cardiovascular drugs - the review of the current clinical evidence. Ther. Clin. Risk Manag. 2019, 15, 1095-1110. [CrossRef]

15. Nakamae, H.; Tsumura, K.; Terada, Y.; Nakane, T.; Nakamae, M.; Ohta, K.; Yamane, T.; Hino, M. Notable effects of angiotensin II receptor blocker, valsartan, on acute cardiotoxic changes after standard chemotherapy with cyclophosphamide, doxorubicin, vincristine, and prednisolone. Cancer 2005, 104, 2492-2498. [CrossRef] [PubMed]

16. Ludke, A.R.; Al-Shudiefat, A.A.; Dhingra, S.; Jassal, D.S.; Singal, P.K. A concise description of cardioprotective strategies in doxorubicin-induced cardiotoxicity. Can. J. Physiol. Pharmacol. 2009, 87, 756-763. [CrossRef]

17. Ma, Y.; Bai, F.; Qin, F.; Li, J.; Liu, N.; Li, D.; Li, T.; Xie, H.; Liu, D.; Zhou, S.; et al. Beta-blockers for the primary prevention of anthracycline-induced cardiotoxicity: A meta-analysis of randomized controlled trials. BMC Pharmacol. Toxicol. 2019, 20, 18. [CrossRef]

18. Tebbi, C.K.; London, W.B.; Friedman, D.; Villaluna, D.; De Alarcon, P.A.; Constine, L.S.; Mendenhall, N.P.; Sposto, R.; Chauvenet, A.; Schwartz, C.L. Dexrazoxane-associated risk for acute myeloid leukemia/myelodysplastic syndrome and other secondary malignancies in pediatric Hodgkin's disease. J. Clin. Oncol. 2007, 25, 493-500. [CrossRef]

19. Seppo, W.L. Dexrazoxane for the treatment of chemotherapy-related side effects. Cancer Manag. Res. 2014, 6, 357-363. [CrossRef]

20. Ojha, S.; Al Taee, H.; Goyal, S.; Mahajan, U.B.; Patil, C.R.; Arya, D.S.; Rajesh, M. Cardioprotective potentials of plant-derived small molecules against doxorubicin associated cardiotoxicity. Oxid. Med. Cell. Longev. 2016, 2016, 5724973. [CrossRef]

21. Lin, H.; Zhang, J.; Ni, T.; Lin, N.; Meng, L.; Gao, F.; Luo, H.; Liu, X.; Chi, J.; Guo, H. Yellow Wine Polyphenolic Compounds prevents Doxorubicin-induced cardiotoxicity through activation of the Nrf2 signalling pathway. J. Cell. Mol. Med. 2019, 23, 6034-6047. [CrossRef] [PubMed]

22. Mohajeri, M.; Sahebkar, A. Protective effects of curcumin against doxorubicin-induced toxicity and resistance: A review. Crit. Rev. Onc. Hematol. 2018, 122, 30-51. [CrossRef] [PubMed]

23. Benzer, F.; Kandemir, F.M.; Ozkaraca, M.; Kucukler, S.; Caglayan, C. Curcumin ameliorates doxorubicininduced cardiotoxicity by abrogation of inflammation, apoptosis, oxidative DNA damage, and protein oxidation in rats. J. Biochem. Mol. Toxicol. 2018, 32, e22030. [CrossRef] [PubMed] 
24. Jafarinezhad, Z.; Rafati, A.; Ketabchi, F.; Noorafshan, A.; Karbalay-Doust, S. Cardioprotective effects of curcumin and carvacrol in doxorubicin-treated rats: Stereological study. Food Sci. Nutr. 2019, 7, 3581-3588. [CrossRef] [PubMed]

25. Sadzuka, Y.; Nagamine, M.; Toyooka, T.; Ibuki, Y.; Sonobe, T. Beneficial effects of curcumin on antitumor activity and adverse reactions of doxorubicin. Int. J. Pharm. 2012, 432, 42-49. [CrossRef]

26. Swamy, A.V.; Gulliaya, S.; Thippeswamy, A.; Koti, B.C.; Manjula, D.V. Cardioprotective effect of curcumin against doxorubicin-induced myocardial toxicity in albino rats. Indian J. Pharmacol. 2012, 44, 73-77. [CrossRef]

27. Junkun, L.; Erfu, C.; Tony, H.; Xin, L.; Sudeep, K.; Mingliang, Z.; Yanqin, W.; XiangQian, Q. Curcumin downregulates phosphate carrier and protects against doxorubicin induced cardiomyocyte apoptosis. Biomed. Res. Int. 2016, 2016, 1980763. [CrossRef]

28. Jain, A.; Rani, V. Mode of treatment governs curcumin response on doxorubicin-induced toxicity in cardiomyoblasts. Mol. Cell. Biochem. 2018, 442, 81-96. [CrossRef]

29. Hosseinzadeh, L.; Behravan, J.; Mosaffa, F.; Bahrami, G.; Bahrami, A.; Karimi, G. Curcumin potentiates doxorubicin-induced apoptosis in $\mathrm{H} 9 \mathrm{c} 2$ cardiac muscle cells through generation of reactive oxygen species. Food Chem. Toxicol. 2011, 49, 1102-1109. [CrossRef] [PubMed]

30. Dei Cas, M.; Ghidoni, R. Dietary Curcumin: Correlation between Bioavailability and Health Potential. Nutrients 2019, 11, 2147. [CrossRef]

31. Giordano, A.; Tommonaro, G. Curcumin and Cancer. Nutrients 2019, 11, 2376. [CrossRef] [PubMed]

32. Sharma, R.A.; Euden, S.A.; Platton, S.L.; Cooke, D.N.; Shafayat, A.; Hewitt, H.R.; Marczylo, T.H.; Morgan, B.; Hemingway, D.; Plummer, S.M.; et al. Phase I clinical trial of oral curcumin: Biomarkers of systemic activity and compliance. Clin. Cancer Res. 2004, 10, 6847-6854. [CrossRef] [PubMed]

33. Kunati, S.R.; Yang, S.M.; William, B.M.; Xu, Y. An LC-MS/MS method for simultaneous determination of curcumin, curcumin glucuronide and curcumin sulfate in a phase II clinical trial. J. Pharm. Biomed. Anal. 2018, 156, 189-198. [CrossRef] [PubMed]

34. Shen, L.; Ji, H.F. The pharmacology of curcumin: Is it the degradation products? Trends Mol. Med. 2012, 18, 138-144. [CrossRef] [PubMed]

35. Shen, L.; Liu, C.C.; An, C.Y.; Ji, H.F. How does curcumin work with poor bioavailability? Clues from experimental and theoretical studies. Sci. Rep. 2016, 6, 20872. [CrossRef] [PubMed]

36. Wang, Y.J.; Pan, M.H.; Cheng, A.L.; Lin, L.I.; Ho, Y.S.; Hsieh, C.Y.; Lin, J.K. Stability of curcumin in buffer solutions and characterization of its degradation products. J. Pharm. Biomed. Anal. 1997, 15, 1867-1876. [CrossRef]

37. Bezerra, D.P.; Soares, A.K.N.; de Sousa, D.P. Overview of the role of vanillin on redox status and cancer development. Oxid. Med. Cell. Longev. 2016, 2016, 9734816. [CrossRef]

38. Dhanalakshmi, C.; Janakiraman, U.; Manivasagam, T.; Thenmozhi, A.J.; Essa, M.M.; Kalandar, A.; Khan, M.A.; Guillemin, G.J. Vanillin attenuated behavioural impairments, neurochemical deficts, oxidative stress and apoptosis against rotenone induced rat model of Parkinson's disease. Neurochem. Res. 2016, 41, 1899-1910. [CrossRef]

39. Bezerra-Filho, C.S.M.; Barboza, J.N.; Souza, M.T.S.; Sabry, P.; Ismail, N.S.M.; de Sousa, D.P. Therapeutic Potential of Vanillin and its Main Metabolites to Regulate the Inflammatory Response and Oxidative Stress. Mini Rev. Med. Chem. 2019, 19, 1681-1693. [CrossRef]

40. Yu, D.; Zhang, S.; Feng, A.; Xu, D.; Zhu, O.; Mao, Y.; Zhao, Y.; Lv, Y.; Han, C.; Liu, R.; et al. Methotrexate, doxorubicin, and cisplatinum regimen is still the preferred option for osteosarcoma chemotherapy: A meta-analysis and clinical observation. Medicine 2019, 98, e15582. [CrossRef]

41. Borriello, M.; Iannuzzi, C.; Sirangelo, I. Pinocembrin Protects from AGE-Induced Cytotoxicity and Inhibits Non-Enzymatic Glycation in Human Insulin. Cells 2019, 8, 385. [CrossRef] [PubMed]

42. Catauro, M.; Tranquillo, E.; Illiano, M.; Sapio, L.; Spina, A.; Naviglio, S. The Influence of the Polymer Amount on the Biological Properties of $\mathrm{PCL} / \mathrm{ZrO}_{2}$ Hybrid Materials Synthesized via Sol-Gel Technique. Materials 2017, 10, 1186. [CrossRef] [PubMed]

43. Lindblom, P.; Rafter, I.; Copley, C.; Andersson, U.; Hedberg, J.J.; Berg, A.L.; Samuelsson, A.; Hellmold, H.; Cotgreave, I.; Glinghammar, B. Isoforms of alanine aminotransferases in human tissues and serum-differential tissue expression using novel antibodies. Arch. Biochem. Biophys. 2007, 466, 66-77. [CrossRef] [PubMed]

44. Iannuzzi, C.; Borriello, M.; Irace, G.; Cammarota, M.; Di Maro, A.; Sirangelo, I. Vanillin Affects Amyloid Aggregation and Non-Enzymatic Glycation in Human Insulin. Sci. Rep. 2017, 7, 15086. [CrossRef] [PubMed] 
45. Schieber, M.; Chandel, N.S. ROS function in redox signaling and oxidative stress. Curr. Biol. 2014, 24, R453-R462. [CrossRef]

46. Zhang, D.X.; Ma, D.Y.; Yao, Z.Q.; Fu, C.Y.; Shi, Y.X.; Wang, Q.L.; Tang, Q.Q. ERK1/2/p53 and NF-kB dependent-PUMA activation involves in doxorubicin-induced cardiomyocyte apoptosis. Eur. Rev. Med. Pharmacol. Sci. 2016, 20, 2435-2442.

47. Zhang, Y.; Shi, J.; Li, Y.; Wei, L. Cardiomyocyte death in doxorubicin-induced cardiotoxicity. Arch. Immunol. Ther. Exp. 2009, 57, 435-445. [CrossRef]

48. Harrison, D.J.; Geller, D.S.; Gill, D.J.; Lewis, V.O.; Gorlick, R. Current and Future Therapeutic Approaches for Osteosarcoma. Expert Rev. Anticancer Ther. 2018, 18, 39-50. [CrossRef]

49. Cai, F.; Luis, M.A.F.; Lin, X.; Wang, M.; Cai, L.; Cen, C.; Biskup, E. Anthracycline-induced cardiotoxicity in the chemotherapy treatment of breast cancer: Preventive strategies and treatment. Mol. Clin. Oncol. 2019, 11, 15-23. [CrossRef]

50. Mohseny, A.B.; Machado, I.; Cai, Y.; Schaefer, K.; Serra, M.; Hogendoorn, P.C.W.; Llombart-Bosch, A.; Cleton-Jansen, A.M. Functional Characterization of Osteosarcoma Cell Lines Provides Representative Models to Study the Human Disease. Lab. Investig. 2011, 91, 1195-1205. [CrossRef]

51. Swain, S.M.; Whaley, F.S.; Gerber, M.C.; Weisberg, S.; York, M.; Spicer, D.; Jones, S.E.; Wadler, S.; Desai, A.; Vogel, C.; et al. Cardioprotection with dexrazoxane for doxorubicin-containing therapy in advanced breast cancer. J. Clin. Oncol. 1997, 15, 1318-1332. [CrossRef] [PubMed]

52. Squillaro, T.; Schettino, C.; Sampaolo, S.; Galderisi, U.; Di Iorio, G.; Giordano, A.; Melone, M. Adult-onset Brain Tumors and Neurodegeneration: Are Polyphenols Protective? J. Cell. Physiol. 2018, 233, 3955-3967. [CrossRef] [PubMed]

53. Damiano, S.; Iovane, V.; Squillacioti, C.; Mirabella, N.; Prisco, F.; Ariano, A.; Amenta, M.; Giordano, A.; Florio, S.; Ciarcia, R. Red Orange and Lemon Extract Prevents the Renal Toxicity Induced by Ochratoxin A in Rats. J. Cell Physiol. 2020, 235, 5386-5393. [CrossRef] [PubMed]

54. Faridvand, Y.; Haddadi, P.; Vahedian, V.; Nozari, S.; Nejabati, H.R.; Pezeshkian, M.; Afrasiabi, A.; Safaie, N.; Jodati, A.; Nouri, M. Human Amnion Membrane Proteins Prevent Doxorubicin-Induced Oxidative Stress Injury and Apoptosis in Rat H9c2 Cardiomyocytes. Cardiovasc. Toxicol. 2020, 20, 370-379. [CrossRef]

55. Amgalan, D.; Garner, T.P.; Pekson, R.; Jia, X.F.; Yanamandala, M.; Paulino, V.; Liang, F.G.; Corbalan, J.J.; Lee, J.; Chen, Y.; et al. A small-molecule allosteric inhibitor of BAX protects against doxorubicin-induced cardiomyopathy. Nat. Cancer 2020, 1, 315-328. [CrossRef]

56. Chen, Y.; Dou, C.; Yi, J.; Tang, R.; Yu, T.; Zhou, L.; Luo, W.; Liang, M.; Yin, X.; Li, J.; et al. Inhibitory effect of vanillin on RANKL-induced osteoclast formation and function through activating mitochondrial-dependent apoptosis signaling pathway. Life Sci. 2018, 208, 305-314. [CrossRef]

57. Tong, Y.; Liu, S.; Gong, R.; Zhong, L.; Duan, X.; Zhu, Y. Ethyl Vanillin Protects against Kidney Injury in Diabetic Nephropathy by Inhibiting Oxidative Stress and Apoptosis. Oxid. Med. Cell. Longev. 2019, 2019, 2129350. [CrossRef]

58. Huang, C.Y.; Chen, J.Y.; Kuo, C.H.; Pai, P.Y.; Ho, T.J.; Chen, T.S.; Tsai, F.J.; Padma, V.V.; Kuo, W.W.; Huang, C.Y. Mitochondrial ROS-induced ERK1/2 Activation and HSF2-mediated AT 1 R Upregulation Are Required for Doxorubicin-Induced Cardiotoxicity. J. Cell. Physiol. 2018, 233, 463-475. [CrossRef]

59. Li, J.M.; Lee, Y.C.; Li, C.C.; Lo, H.Y.; Chen, F.Y.; Chen, Y.S.; Hsiang, C.Y.; Ho, T.Y. Vanillin-Ameliorated Development of Azoxymethane/Dextran Sodium Sulfate-Induced Murine Colorectal Cancer: The Involvement of Proteasome/Nuclear Factor-kB/Mitogen-Activated Protein Kinase Pathways. J. Agric. Food Chem. 2018, 66, 5563-5573. [CrossRef]

60. Cheng, W.Y.; Hsiang, C.Y.; Bau, D.T.; Chen, J.C.; Shen, W.S.; Li, C.C.; Lo, H.Y.; Wu, S.L.; Chiang, S.Y.; Ho, T.Y. Microarray analysis of vanillin-regulated gene expression profile in human hepatocarcinoma cells. Pharmacol. Res. 2007, 56, 474-482. [CrossRef]

61. Srinual, S.; Chanvorachote, P.; Pongrakhananon, V. Suppression of cancer stem-like phenotypes in NCI-H460 lung cancer cells by vanillin through an Akt-dependent pathway. Int. J. Oncol. 2017, 50, 1341-1351. [CrossRef] [PubMed]

62. Naz, H.; Tarique, M.; Khan, P.; Luqman, S.; Ahamad, S.; Islam, A.; Ahmad, F.; Hassan, M.I. Evidence of vanillin binding to CAMKIV explains the anti-cancer mechanism in human hepatic carcinoma and neuroblastoma cells. Mol. Cell. Biochem. 2018, 438, 35-45. [CrossRef] [PubMed] 
63. Elsherbiny, N.M.; Nahla, N.Y.; Mohamed, A.S.; Mohamed, M.E. The Synergistic Effect Between Vanillin and Doxorubicin in Ehrlich Ascites Carcinoma Solid Tumor and MCF-7 Human Breast Cancer Cell Line. Pathol. Res. Pract. 2016, 212, 767-777. [CrossRef] [PubMed]

64. Ho, K.; Yazan, L.S.; Ismail, N.; Ismail, M. Toxicology study of vanillin on rats via oral and intra-peritoneal administration. Food Chem. Toxicol. 2011, 49, 25-30. [CrossRef] [PubMed] 